\title{
Measuring the Alignment of BSC with the Egyptian Travel \& Leisure Organizations
}

\section{Emad Elwy Habib}

Lecturer (Ph.D.), Management \& Systems Department, Faculty of Management Sciences, Modern Sciences and Arts University MSA, Egypt.

\section{Abstract:}

Performance Measurement by leaps and bond became a focus in Travel \& Leisure industry. Balanced Scorecard (BSC) is a performance measurement and strategic management framework which appears suitable for use by all types and sizes of business. BSC is one of the most prominent approaches in this context, which Identifies a critical set of key performance indicators that measures and evaluate the performance of these organizations. The BSC's greatest strength for most businesses comes from its innate ability to integrate financial and non-financial measures together by measuring both strategic and business performance across four interrelated perspectives. The researcher used the Balanced Scorecard (BSC) as a tool for developing a proposed model to evaluate the performance in Travel \& Leisure industry. This research formulates a new multidimensional model inspired from BSC to be used as a performance 
Measuring the Alignment of BSC with the Egyptian Travel

measure tool in the Travel \& Leisure organizations with special emphasize, addressing performance evaluation of on Egyptian organizations, through the four perspectives of the balance scorecard: client, internal operating processes, employees' innovation/learning and growth, and financial. by identifying the process that encompasses its inputs, processing, and outputs, addresses performance evaluation. In addition to the identification of the constructs and variable suitable for each perspective. The research is a critical trial to identify the key concerns of the travel and leisure organizations quality of service throughout performance improvement. 


\section{(الملخص:}

بقزز ات ووثبات إعتبر تقييم الأداء محل ثركيز وإهتمام من قبل شركات

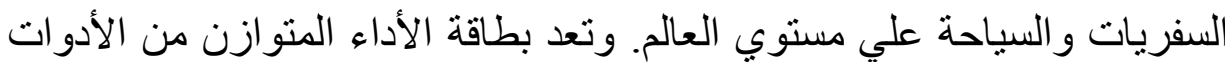

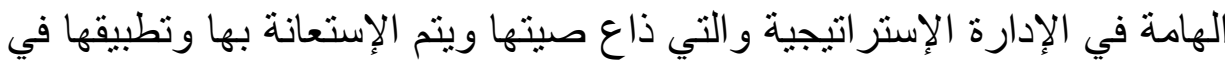

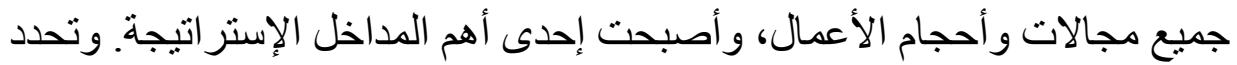

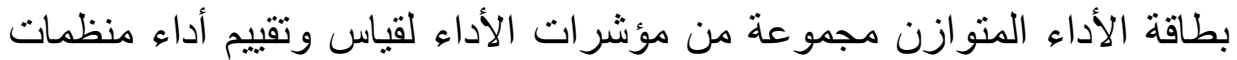

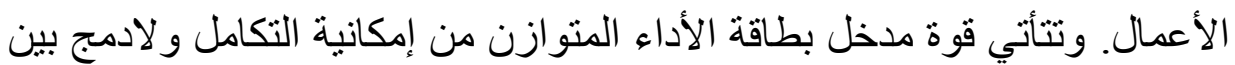

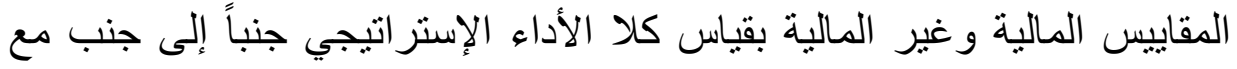

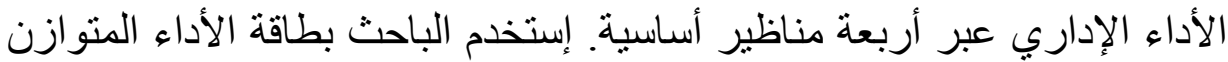

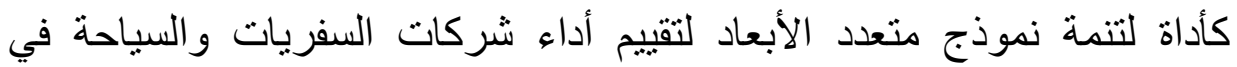
جمهورية مصر العربية، من خلال أربعة مناظير أساسية: المنظور الأول وهودان

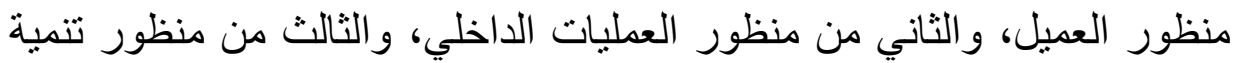

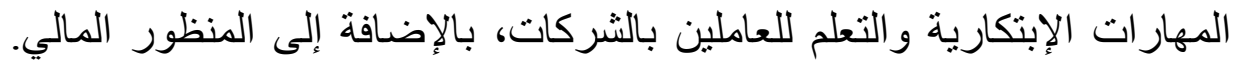

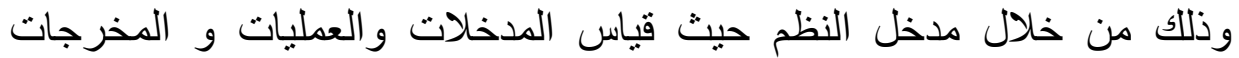

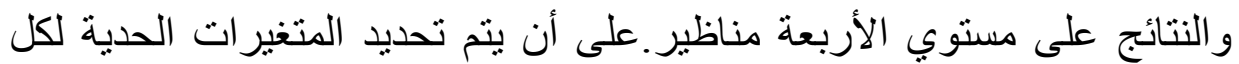
منظور على حدًا لتقييم أداء الخدمات المقدمة من شركات السفريات ولى الساحة المصرية. 
Measuring the Alignment of BSC with the Egyptian Travel

Emad Elwy Habib

\section{Purpose:}

This study evaluates the performance measurement of 4 travel and leisure organizations in Great Cairo, representing best practice of Travel and Leisure industry in Egypt, in an attempt to assess whether Egyptian travel and leisure organizations can cope with the aspects of the BSC model developed in this research as a tool for performance evaluation.

\section{Research limitations:}

The outcomes of the research based on a limited survey that were disseminated 40 travel \& leisure organizations within a geographical area located in Great Cairo and 350 questionnaires distributed travel \& Leisure organizations top, middle, and first line managers; it is recognized that further research is necessary to establish the exact nature of the causal linkages between performance measures and strategic intent and also, to gain insights into practice elsewhere.

\section{Key Words:}

Egyptian Travel and Leisure Industry, Performance Measurement Framework, performance evaluation, Balanced Scorecard (BSC).

\section{Research Problem:}

Monitoring measurements of business success like the internal operating processes measures can be detrimental to 
Measuring the Alignment of BSC with the Egyptian Travel

any industry and especially to Travel and Leisure industry. Travel and leisure organizations should employ a comprehensive view of measurements, including equal emphasis on a group of performance indicators other than the financial one. The lack of efficient data collection, reporting, and process improvement methodology may hinder the implementation of the modified BSC.

\section{Objectives:}

1. Measuring the impact of BSC framework on performance of Travel and Leisure organization.

2. Investigating the sample responses towards the BSC perspectives and the organization's performance.

3. Measuring the effects of internal operational processes perspective and Employee innovation/learning and growth Perspective, on the financial performance perspective taking into consideration the client prospective.

4. To measure the validity of the proposed model for improving the performance of the Travel and Leisure industry.

\section{Hypotheses:}

1. There is no significant relationship between BSC framework and the Travel and Leisure organization's performance. 
Measuring the Alignment of BSC with the Egyptian Travel

2. There is no effect of the internal constructs of BSC framework (Internal operating processes, and Employee innovation/learning and growth Perspective) on the financial performance taking into consideration the client prospective.

3. There are no significant statistical differences between sample responses towards the BSC perspectives and the organization performance.

4. The proposed new model is not a valid tool for improving the performance of the Travel and Leisure industry.

\section{Introduction:}

Giannopoulos, George, (2013), argued that the Balanced Scorecard (BSC) is a strategic performance management framework used by many organizations in the international business environment. To my point of view, the bar of competition is getting higher in terms of the notorious current globalization that forces organizations to seek strategic planning methods, that enable them to survive, develop, and continually compete striving for their market share at present and in the future. Balance Score Card appeared as a strategic organizational framework for setting performance indicators measures to improve the organizations performance. Kaplan, R. S. \& Norton, D. P. (1992) as the creators claim that 
Measuring the Alignment of BSC with the Egyptian Travel

Emad Elwy Habib

Improving the performance of firms is a major challenge, particularly for developing countries. In traditional performance measurement approach, the most important goals of evaluation are performance measurement while modern approach has focused on evaluated growth and development capacity (Niknazar, 2009). Traditional performance measures are not relevant. The challenge is to devise new internal managerial frameworks that will be supportive of the firm's new strategy. Improving managerial performance measures based on achieving these strategic goals should be developed to replace the current emphasis on short-term Peter Drucker in 1954 argued that one potential solution was to introduce "balanced" sets of measures. Market standings, innovation, productivity, physical and financial resources, profitability, manager performance and development, worker performance and attitude, and public responsibility are appropriate performance criteria (Neely, 2005). Modern evaluation framework results in satisfaction, efficiency, and finally effectiveness improvements of organizational activities (Norton, 1999). As a way to measure nonfinancial performance in an organization, Kaplan and Norton, (1996), introduced balanced scorecard approach which balanced, client, internal operations process, and innovation/learning and growth measures against traditional financial measures. Financial indicators never tell the entire story of an 
Measuring the Alignment of BSC with the Egyptian Travel

Emad Elwy Habib

organization, since talent organizational culture, and client relationships go a long way toward dictating future financial performance. Bititci, Carrie, Mcdevitt, (1997), defined performance management framework as Information framework which is at the heart of the performance management process, and it is of critical importance to the effective and efficient functioning of the performance management. Performance management framework defined by Salem, M. et, al., (2012), Artelly (2001) as; The heart and soul of the performance-based management process. Flowing from the organizational mission, vision, and the strategic planning process, it provides the data that will be collected, analysed, reported, and, ultimately used to make sound business decisions.

\section{The balanced scorecard (BSC) performance measures in travel \& leisure organizations:}

The Balanced Scorecard (BSC) is a strategic performance management framework used by many organizations in the international business environment. According to Kaplan and Norton (1992; 1996a), the creators of BSC, this tool can balance both the financial and nonfinancial measures that any organization uses. It split into four interrelated perspectives: client perspective, internal operations perspective, innovation and learning perspective 
Measuring the Alignment of BSC with the Egyptian Travel

Emad Elwy Habib

and financial perspective. According to Gumbus \& Lussier (2006), the BSC can be used in both large and small businesses if employees are working towards achieving the same targets and strategic goals. According to the results of Rigby and Bilodeau, (2011), Numerous surveys have provided evidence as to the BSC's popularity and widespread implementation by different types of organization Although the BSC has been successfully adopted by many large corporate businesses and non-profit organizations, it has been subject to criticism from both theorists and practitioners (Kaplan and Norton, 2001; Norreklit 2000). Despite its critics, the BSC has produced tangible benefits for many of the large organizations who have chosen to implement it. Theorists predict similar benefits for smaller organizations and entities who decide to adopt and implement the BSC (Bergen and Benco, 2004).

\section{Balanced Scorecard evolution: from performance} management framework to integrated management frameworks:

Perkins et al., (2014) provide a taxonomy for the different versions of the BSC through a process of identifying and labelling the major and minor changes that have occurred. This allows a more nuanced analysis of the BSC as a tool for managing performance and adding precision to any critique, 
Measuring the Alignment of BSC with the Egyptian Travel

Emad Elwy Habib

in that it is clear which version has been used. They proposed four generations of the BSC split into eight separate versions. The first is split into four different versions: The first laying the groundwork for the scorecard concept; The second beginning to focus on strategy; The third introducing specific targets, developing the strategy and introducing causality; and The fourth highlighting the role the scorecard plays as part of a Performance Measurement system (PMS). Kaplan and Norton stated that in order to have an integrated organization performance assessment, the performance should be noticed from four aspects; These four perspectives answer to four key questions: How should we be in client view? In which internal processes we should transcend? Can we stand in continuous improvement and value creativity? How should we be in our shareholders' view?

2.1. The first generation of BSC consists of above perspectives in addition to goal and metric in each perspective. These four perspectives in their first generation are explaining as follows:

2.1.1. Client perspective: The prominent factors of the any organization mission statement focuses on clients. Throughout creating him a value that gets beyond his expectations. BSC supports managers interpret mission statement in four necessary for clients in four categories: time, quality, performance and service delivery, and price, that express their

العك المثانى

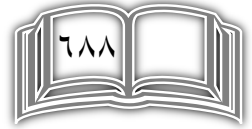
المجلد السابع 
Measuring the Alignment of BSC with the Egyptian Travel

Emad Elwy Habib

goals into specific metrics (Anderson and Sullivan, 1994). Poureisa, Arman, et al., (2013) argued that Managers need to focus on those key internal operations that develops their capabilities to meet clients' expectations. The client perspective focuses on the clients' opinion for the organization, and how the organization wants to be viewed by its clients (Norreklit, 2000), and can also act as a very important key performance indicator on the efforts of the business to be successful (Anderson and Sullivan, 1994). Therefore, the organization has to align its targets according to these four elements, and subsequently transform these targets into specific measures (Kaplan and Norton, 1992).

\subsubsection{Internal operational processes perspective:}

Giannopoulos, George, (2013), argued should be aligned on the business processes that focuses on the most effective activities an organisation undertakes to satisfy its clients. Organizations should decide in which processes they want to be at top and define each metric related to these items. that the internal business perspective focuses on the activities an organisation undertakes to satisfy its clients.

2.1.3. Learning and growths perspective: After the metrics and goals related to internal processes and client perspectives identified, it is possible to understand that there is a gap between current organizational infrastructures and optimized level in order to achieve the goals. However, universal close 
Measuring the Alignment of BSC with the Egyptian Travel

competition makes organizations consider a continuous improvement in their products and/or services and processes and capable enough to identify new products and/or services. The organization capability in innovation, improvement, and learning directly affects the organization value. In other words, organizations just by their capabilities in providing new products and/or services, creating value for their clients and continuous improvement of operational efficiency can enter new markets and increase their profit and income, (Kaplan and Norton, 1992). Giannopoulos, George, (2013) reached to a result that the innovation and learning perspective focuses on the capabilities and skills that the organization must excel at to achieve superior internal business processes that create value for clients and shareholders. Some of the performance measures that might be used to measure innovation and learning include employee education and skill level, employee satisfaction and retention rates.

2.1.4. Financial perspective: Refers to the financial view of an organization as concerned by its shareholders and if their organizational strategy execution contributed to the first line managers and the non-managerial employees' improvement. Metrics of financial perspective identify that whether the strategy and its execution plays a role in organization profitability improvement or not. Financial goals are usually being defined in relation with profitability, growth and 
Measuring the Alignment of BSC with the Egyptian Travel

shareholders' value. Organizations should define their financial perspective goals in a framework of sustainability, success, and rapid economic wealth growth by cash flow, success by seasonal sell growth, sections operational income, and economic boom by market share and ROI improvements, growth, profitability and shareholder value (Kaplan and Norton, 1996a). Organizations should not use only financial data but also strategic models and measurements that emphasize the overall strategy. Some of the financial measures that can be used are: gross margin percentage, cost reductions and cut specific areas, ROI, and return on capital employed (Kaplan and Norton, 1996a; Collis, Holt and Hussey, 2012). Although the main goal of BSC first generation was to make a balance between financial numbers and future value creator derivers in organization performance evaluation, however, Kaplan and Norton didn't give a distinct and clear definition of "what is a balanced scorecard?" and just explained how to apply it and talked about BSC in relation to other organizational factors.

2.2. BSC second generation is characterized by introducing first version strategy maps, and the further development of this concept alongside the change to bottom-up ongoing approach to the scorecard concept in the second version, Robert Kaplan and David Norton (1996), translated strategy form the theoretical framework to action throughout 
Measuring the Alignment of BSC with the Egyptian Travel

suggesting the cause-and-effect relationship between performance deriver metrics through lead and lag indicators. In general, in second generation three key improvements created in balanced scorecard: Choosing metrics based on clear strategic goals. To identify cause-and-effect relationship among strategic goals that results in designing in a strategic communicational model. Creating four new managerial processes which by using them, BSC transformed from a performance evaluation framework to a strategic management framework.

2.3. The third generation of the BSC identified has two versions, with the first characterized by the addition of the "destination statement" to the BSC and a greater focus on the strategic linkage model, while the second version simplifies the scorecard by removing many of the perspectives that are considered in earlier versions. The particular version of the BSC chosen for implementation must be carefully matched to the organization's needs to ensure success. Throughout the third Generation of BSC there were still some weaknesses in the second generation BSC concepts and identification. Although Kaplan and Norton could not overcome the weaknesses of metrics selection, however, there were still some other problems. In $2^{\text {nd }}$ generation strategic communicational model used to provide a cause-and-effect relationship which was starting from client perspectives, 
Measuring the Alignment of BSC with the Egyptian Travel

Emad Elwy Habib

learning and growth and by passing internal operations processes and finally was ending to financial perspective. Many experts such as Kennerley, Neely, (2002), argued that these cause-and-effect relationship is unsuitable for many organizations and necessarily do not link to macro goals and vision of the organization. Because BSC method does not have any monitoring and control on competitors and technological development; therefore, cannot be considered as a strategic control model. Mac Adam and Maisel (1992), Poureisa, et, al., (2013), reviewed BSC based on TQM framework and explained that TQM as a strategic management are the main organization strategy factors which should be evaluated and measured. Therefore, balanced scorecard is only a tool to evaluate and measure organization strategies and not a decision-making and strategy selection tool. Kaplan and Norton added new metrics to the second generation of $\mathrm{BSC}$ in order to increase strategic communication and created the third generation of BSC based on these changes. In the late 1990, two other metrics, strategic destination and strategic themes were added to BSC. In addition, cause-effect relationship model in last level equipped with a more accurate tool which named strategy map.

2.4. Fourth generation of balanced scorecard Robert Kaplan, (2008), answered the question "what are the most important factors to execute strategies?" He stated that without effective 
Measuring the Alignment of BSC with the Egyptian Travel

Emad Elwy Habib

leadership no strategy can execute successfully and after that linking the strategy to operations is necessary. Both strategy and operation are important but their performance in comparison to each other is quite different. Conclusion in a research Kaplan and Norton found out that 54\% of organizations under the research were using a formal process of strategy execution management. $70 \%$ of these firms have obtained a better performance in comparison to the similar firms group. Using a formal framework to execute the strategy makes the probability of success, two or three times higher. In 2008 Kaplan and Norton identified management frameworks which cause to integration of strategy compiling tools and operations management such as mission statement, vision, strategy compiling methodology, dynamic budgeting and resource allocation, quality methodology and process improvement, learning organization and statistical and economic analysis tools (Kaplan and Norton, 2008).

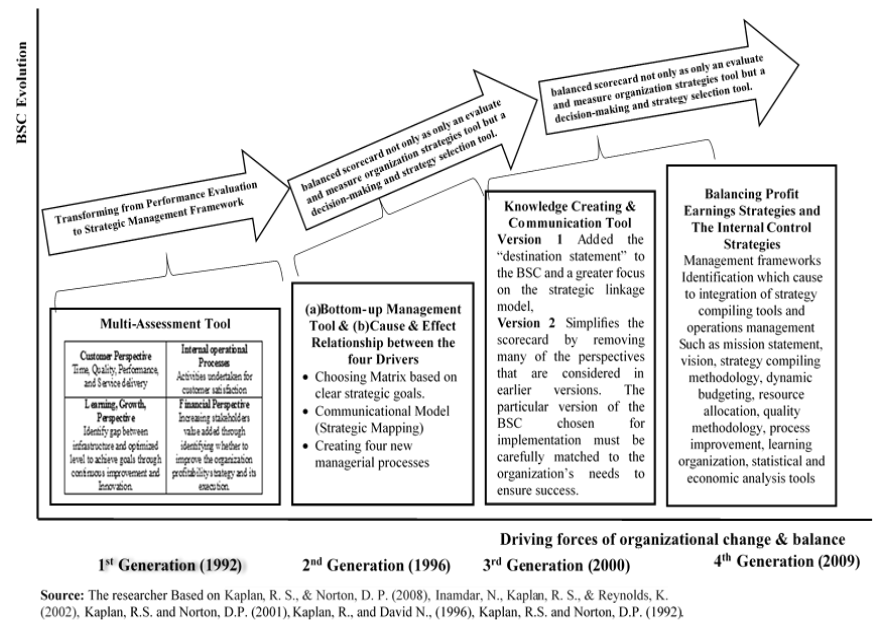

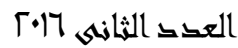




\section{Proposed Model:}

The research adopts a multidimensional model of BSC to measure the performance of travel and leisure organizations in Egypt the model encompasses four dimensions; inputs, process, outputs, and measures. Brown, \& McDonnell, (1995) argued that Considering the model inputs (drivers) and how they are managed depends on the mutual value added between stakeholder and their business. i.e. the stockholders never be attained unless they bring values to their business. It is therefore the satisfaction levels of the employees, clients and society together with the satisfaction of the business needs and wants that drive the business results. Overall, it is the measure and attainment of both the business's wants and needs and the stakeholder's wants and needs that indicate the success of the business at any one point in time. Consequently, with ongoing review of the outputs and outcomes (via their related measures) managers can determine if the attainment of the set goal is sustainable and whether the core organisational strategies are appropriate.

Hao-Chen Huan, (2007), implied that although the inputsoutputs model helps in explaining the performance process in a very simple linear approach, prior research in this area have concluded that the interactions between inputs and outputs are much more complex. The researcher undertaken this model in order to handle the four perspectives of the balance scorecard 
Measuring the Alignment of BSC with the Egyptian Travel

Emad Elwy Habib

by identifying the inputs, process, outputs and measures suitable for each perspective. The researcher tried to identify the key concern of the travel and leisure organizations travel \&leisure organizations to the quality of service through improving the performance measures of the four perspectives of the balance scorecard for a better understanding of dimensions of performance measurement in these organizations. Figure (2) the proposed model for travel and leisure industry:

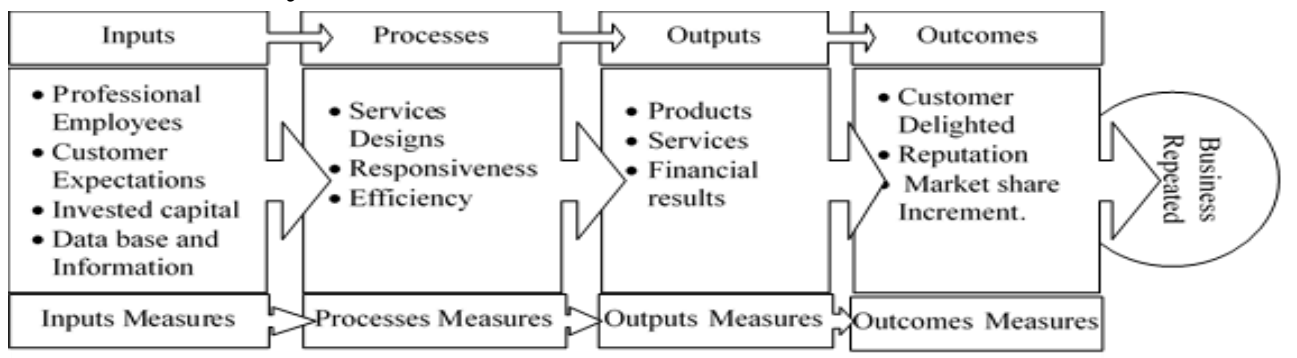

Source: The researcher base d on: Brown, (1995), Phillips, Paul \& Louvieris, Panos, (2010)

Figure (2): Inputs, Processes, Outputs and Outcomes

\section{Client perspective:}

Client satisfaction is the ultimate goal of travel \&leisure organizations. Table (1) shows a trial to design the client perspective measures in travel \& leisure organizations. (Kaplan and Norton, 1996a; Collis, Holt and Hussey, 2012). Communication with clients build relationships and encourage loyalty. Face-to-face interaction between clients and staff assist the collection of performance indicators. A client history can also be built up through informal exchanges. linking communication, educating, goals setting, and linking 
Measuring the Alignment of BSC with the Egyptian Travel

\section{Emad Elwy Habib}

rewards to performance measures intense the organization reputation, consequently clients being more likely to return if they feel valued. Collating and interpreting client satisfaction information, particularly in terms of anecdotal feed- back, must be systematic and rigorous; digitizing MIS should1 facilitate this process. (Brown, 1995, Phillips, Paul \& Louvieris, Panos, 2005, NAGY, A., et, al., 2010).

Table (1): Client perspective of the proposed model

\begin{tabular}{|c|c|c|c|}
\hline Input & Process & Output & Measures \\
\hline Clients & $\begin{array}{l}\text { 1. Building client detailed } \\
\text { profiles: } \\
\text { a- Reservation form. } \\
\text { b- Client comments. } \\
\text { c- Frequency of reservations. } \\
\text { d- Client satisfaction. } \\
\text { e Clients complains } \\
\text { regarding services. } \\
\text { 2. Adequacy of Marketing } \\
\text { materials for attracting } \\
\text { clients. } \\
\text { 3. Communication with clients. } \\
\text { 4. Client profiling } \\
\end{array}$ & $\begin{array}{l}\text { 1. Satisfied } \\
\text { client } \\
\text { 2. New Clients } \\
\text { 3. Building } \\
\text { clients } \\
\text { relationships }\end{array}$ & $\begin{array}{l}\text { 1. Number of regular and } \\
\text { satisfied clients out of the total } \\
\text { clients of specific period } \\
2 \text {. Number of new clients from } \\
\text { specific areas subject to specific } \\
\text { marketing technique. } \\
\text { 3. clients being more lilely to } \\
\text { return if they feel valued. } \\
\text { 4. Anecdotal feedbackvia staff } \\
\text { 5. Client satisfaction lev els. } 6 \text {. } \\
\text { Average spend } \\
\text { 7. Client satisfaction lev els } \\
\text { 8. Client retention rate }\end{array}$ \\
\hline $\begin{array}{l}\text { Reservations } \\
\text { conditions }\end{array}$ & $\begin{array}{l}\text { Providing clients with the most } \\
\text { comfortable services }\end{array}$ & client satisfied. & Number of complains \\
\hline $\begin{array}{l}\text { Service } \\
\text { Quality }\end{array}$ & $\begin{array}{l}\text { 1. mystery client initiative. } \\
\text { 2. workwith focus groups from } \\
\text { across clients' data base. } \\
\text { 3. undertake benchmarking } \\
\text { with competitors, nationally } \\
\text { and internationally. }\end{array}$ & $\begin{array}{l}\text { 1. client } \\
\text { satisfaction } \\
\text { 2. client } \\
\text { retention. } \\
\text { 3. Quality of } \\
\text { Sevice }\end{array}$ & $\begin{array}{l}\text { 1. the grading schemes offered } \\
\text { by organizations } \\
\text { 2. Client surveys } \\
\text { 3. Mystery client } \\
\text { 4. Participation in grading } \\
\text { schemes }\end{array}$ \\
\hline
\end{tabular}

\section{Internal operations process perspective:}

The Internal operations process perspective is concerned with improvement done in the organization as a result of the feedback of the other perspectives. As shown in table (2),

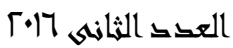

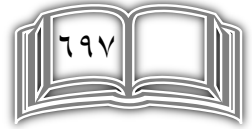
المجلد السابع 
Measuring the Alignment of BSC with the Egyptian Travel

(Kaplan and Norton, 1996a; Collis, Holt and Hussey, 2012). this perspective was designed to improve the Internal operations process of the organization by using more representative measures into consideration and compares these measures with other organization or to match with qualifying standards of Business Planning, goal setting, strategic initiatives, allocating resources, and establishing milestones. (Brown, 1995, Phillips, Paul \& Louvieris, Panos, 2005, NAGY, A., et, al., 2010).

Table (2): Internal operations process perspective of the proposed model

\begin{tabular}{|c|c|c|c|}
\hline Input & Process & Output & Measures \\
\hline $\begin{array}{l}\text { Time to serve } \\
\text { client }\end{array}$ & $\begin{array}{l}\text { keeping records for time tahen } \\
\text { by each client. } \\
\text { Clients Follow wp }\end{array}$ & $\begin{array}{l}\text { Minimum time to } \\
\text { serveclient } \\
\text { Quickresponse }\end{array}$ & Number of minutes serving each client \\
\hline Service quality & $\begin{array}{l}\text { Investing in staff } \\
\text { Staff satisfaction surveys }\end{array}$ & $\begin{array}{l}\text { Staff development } \\
\text { reviers }\end{array}$ & Staff retention rate percentage \\
\hline $\begin{array}{l}\text { Monitoring of } \\
\text { facilities }\end{array}$ & $\begin{array}{l}\text { Continuous update for the } \\
\text { facilities } \\
\text { Multifactor productivity }\end{array}$ & $\begin{array}{l}\text { Updated facility used } \\
\text { by client } \\
\text { Wages (\%) to achiere } \\
\text { turnover }\end{array}$ & $\begin{array}{l}\text { Number of improvements presented. } \\
\text { Staff incentive schemes (eg, performance- } \\
\text { related pay) }\end{array}$ \\
\hline Strategy design & $\begin{array}{l}\text { 1. Having clear objectives } \\
\text { 2. Encouraging clients to } \\
\text { participate in strategy design } \\
\text { 3. Encourage administrative } \\
\text { staff to participate in strategy } \\
\text { design. } \\
\text { 4. Tracking objectives } \\
\text { 5. Internal auditing }\end{array}$ & $\begin{array}{l}\text { 1. Meeting financial } \\
\text { targets } \\
\text { 2. Widely accepted } \\
\text { strategy. } \\
\text { 3. Less resistant from } \\
\text { administrative staff } \\
\text { 4. Completion of } \\
\text { capitalprojects }\end{array}$ & $\begin{array}{l}\text { 1. Number of clients' participants in } \\
\text { strategy design. } \\
\text { 2. T he percentage of participation by each } \\
\text { employee }\end{array}$ \\
\hline $\begin{array}{l}\text { Error reports } \\
\text { received }\end{array}$ & $\begin{array}{l}\text { Analysis of the error reports and } \\
\text { act uponit }\end{array}$ & Correction of errors & $\begin{array}{l}\text { 1-Number of Service errors reported and } \\
\text { handled } \\
\text { 2-Complain response }\end{array}$ \\
\hline
\end{tabular}

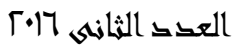

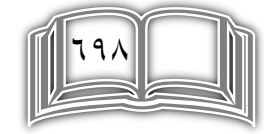
المجلد السابع 


\section{Employee Innovation/learning and growth perspective:}

Employee innovation/learning and growth Perspective discuss the ways to improve the staff capability through training, development sessions, and practical training in international travel \&leisure organizations conducted by specialized entities. As shown in table (3), (Kaplan and Norton, 1996a; Collis, Holt and Hussey, 2012). Feedback \& Learning, articulating the shared vision, supplying strategic feedback, and facilitating strategy review \& learning. (Brown, 1995, Phillips, Paul \& Louvieris, Panos, 2005, NAGY, A., et, al., 2010).

Table (3): Employee Innovation/learning and growth perspective of the proposed model

\begin{tabular}{|c|c|c|c|}
\hline Input & Process & Output & Measures \\
\hline $\begin{array}{l}\text { Training } \\
\text { programs }\end{array}$ & $\begin{array}{l}\text { Providing training programs for } \\
\text { staff. }\end{array}$ & $\begin{array}{l}\text { Specialized and } \\
\text { qualified staff } \\
\text { members. }\end{array}$ & $\begin{array}{l}\text { 1-Number of staff members } \\
\text { attended the training courses. } \\
\text { 2-Training hurs per employees }\end{array}$ \\
\hline $\begin{array}{l}\text { Staff } \\
\text { improv ement } \\
\text { and der dopment }\end{array}$ & $\begin{array}{l}\text { 1-Conferences attended by the } \\
\text { members. } \\
\text { 2-The scholarships provided to the } \\
\text { staff menber to get academic or } \\
\text { professional degrees from abroad. } \\
\text { 3-Review of the administrative } \\
\text { employee's qualifications. } \\
\text { 4-Encourageing the employees by } \\
\text { providing a full time contracts } \\
\text { instead of part time contracts. } \\
\text { 5. Encouraging teamwork } \\
\text { 6. Cross-sector comparison } \\
\text { 7. Participation in grading schemes } \\
\text { 8. Process improvement initiatives }\end{array}$ & $\begin{array}{l}\text { 1. expert staff. } \\
\text { 2. Improving the staff } \\
\text { qualification. } \\
\text { 3. highly qualified } \\
\text { employees } \\
\text { 4. job satisfaction } \\
\text { and loyalty. } \\
\text { 5. Staff as drivers of } \\
\text { innovation. } \\
\text { 6. Networking } \\
\text { relationships } \\
\text { 7. Membership of } \\
\text { trade'professional } \\
\text { bodies }\end{array}$ & $\begin{array}{l}\text { 1. Number of conferences held. } \\
\text { 2. Number of staff menbers } \\
\text { obtained an academic degree from } \\
\text { abroad. } \\
\text { 3. T he number of promotions } \\
\text { granted each year to the } \\
\text { administrative staff based on } \\
\text { qualification } \\
\text { 4. T he number of full time } \\
\text { contracts granted to the qualified } \\
\text { part time employees. } \\
\text { 5. Number of new products/services } \\
\text { 6. Courses completed by staff } \\
\text { 7. Le el of multiskilling } \\
\text { Productivity }\end{array}$ \\
\hline $\begin{array}{l}\text { Performance } \\
\text { Evaluation } \\
\text { system for staff }\end{array}$ & $\begin{array}{l}\text { Matching staff appraisal their job } \\
\text { descriptions }\end{array}$ & $\begin{array}{l}\text { 1. Accurate and fair } \\
\text { Staff Appraisal } \\
\text { 2. Absenteeism rate } \\
\text { decrease }\end{array}$ & $\begin{array}{l}\text { Reports indicate the performance } \\
\text { of the staff as a percent out of } 100 \\
\text { depending on the market situation. }\end{array}$ \\
\hline Employee & $\begin{array}{l}\text { Design a unified procedures for } \\
\text { recruiting personnel }\end{array}$ & $\begin{array}{l}\text { Recruiting Qualified } \\
\text { E nployees }\end{array}$ & $\begin{array}{l}\text { Number of processed recruit } \\
\text { application. }\end{array}$ \\
\hline $\begin{array}{l}\text { Resigmations of } \\
\text { employees }\end{array}$ & $\begin{array}{l}\text { Processing resignation forms with } \\
\text { cognitive reasons. }\end{array}$ & $\begin{array}{l}\text { Decreasing number } \\
\text { of exiting employees. }\end{array}$ & \\
\hline
\end{tabular}

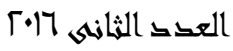

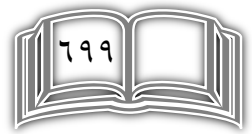
المجلد السايع 
Measuring the Alignment of BSC with the Egyptian Travel

\section{Financial perspective:}

The financial perspective is the main aim of any profitoriented organization. Translating, clarifying the vision, and gaining consensus are the core factors of this perspective which should be taken into consideration with the other three perspectives on an equal basis and not as the only perspective to be taken care of. (Kaplan and Norton, 1996a; Collis, Holt and Hussey, 2012). The travel \&leisure organizations need the resources in order to achieve the other three perspectives. So, the resources available for the travel \&leisure organizations must be used wisely and to achieve the strategic objectives of the travel \&leisure organization without any exaggeration in expenses. As shown in table (4), the recourses assigned to the travel \&leisure organizations must be controlled by efficient and effective measures. (Brown, 1995, Phillips, Paul \& Louvieris, Panos, 2005, NAGY, A., et, al., 2010). 
Table (4): Financial perspective of the proposed model

\begin{tabular}{|c|c|c|c|}
\hline Input & Process & Output & Measures \\
\hline $\begin{array}{l}\text { Adequacy of } \\
\text { resources }\end{array}$ & $\begin{array}{l}\text { 1. keep Records of all types of } \\
\text { expenses, with accurate forecasts. } \\
\text { 2. linking digitized financial } \\
\text { reporting systems and management } \\
\text { information systems. }\end{array}$ & $\begin{array}{l}\text { Up-to-date rexords of } \\
\text { expenses. }\end{array}$ & $\begin{array}{l}\text { Monitoring the amount of } \\
\text { expenses ov ex time series of } \\
\text { years with a periodical review } \\
\text { with the forecasts. }\end{array}$ \\
\hline T he client cost & keep record of the client. & $\begin{array}{l}\text { Adequacy of resources to } \\
\text { reach the excellency in } \\
\text { providing high quality } \\
\text { service. }\end{array}$ & The average cost per client \\
\hline $\begin{array}{l}\text { Overhead } \\
\text { E xpenses } \\
\text { allocation } \\
\end{array}$ & $\begin{array}{l}\text { Determining the percentage of each } \\
\text { expense to the total cost. }\end{array}$ & $\begin{array}{l}\text { Objectivity in allocating } \\
\text { the overhead for each } \\
\text { type of expenses. }\end{array}$ & $\begin{array}{l}\text { Comparing the cost allocation } \\
\text { base with those of other Trave } \\
\text { \&leisure organizations abroad. }\end{array}$ \\
\hline $\begin{array}{l}\text { Income } \\
\text { statements }\end{array}$ & $\begin{array}{l}\text { Comparing the totalprofit of the } \\
\text { organization with time series analysis }\end{array}$ & $\begin{array}{l}\text { Assessing the } \\
\text { performance of the } \\
\text { organization compared } \\
\text { with the prev ious year } \\
\text { results }\end{array}$ & $\begin{array}{l}\text { Total opera ting net profit over } \\
\text { time series analysis }\end{array}$ \\
\hline $\begin{array}{l}\text { T he number of } \\
\text { reservations and } \\
\text { detailed cost } \\
\text { information }\end{array}$ & $\begin{array}{l}\text { Calculating the contribution margin } \\
\text { achieved by each reservation }\end{array}$ & $\begin{array}{l}\text { The ability of the travel } \\
\text { \& leisure organization to } \\
\text { determine the } \\
\text { reservations needed to } \\
\text { achieve specific financial } \\
\text { objective }\end{array}$ & $\begin{array}{l}\text { Contribution margin per } \\
\text { reservation }\end{array}$ \\
\hline $\begin{array}{l}\text { T he actual and } \\
\text { budget cost } \\
\text { reports }\end{array}$ & $\begin{array}{l}\text { Comparing the budget cost with the } \\
\text { actual cost figures }\end{array}$ & $\begin{array}{l}\text { 1. Determining the } \\
\text { variances between the } \\
\text { budget and actual costs } \\
\text { in order to enhance the } \\
\text { ability of the managers } \\
\text { for taking decisions } \\
\text { related to cost control } \\
\text { 2. Budgetary Control }\end{array}$ & $\begin{array}{l}\text { Cost saving and variance } \\
\text { analysis for Cost vs, budget } \\
\text { Adhering to budget } \\
\text { Meeting financial targets } \\
\text { Achieving predicted room and } \\
\text { occupancy rates } \\
\text { Revenue per reservation Cash } \\
\text { flow }\end{array}$ \\
\hline $\begin{array}{l}\text { Financial } \\
\text { Statements }\end{array}$ & $\begin{array}{l}\text { Financial Ratios and E conomical } \\
\text { Value Added (EVA) }\end{array}$ & $\begin{array}{l}\text { 1. Assessing and } \\
\text { enhancing the financial } \\
\text { performance of the } \\
\text { organization } \\
\text { 2. Profitability }\end{array}$ & $\begin{array}{l}\text { 1. Comparing financialratios of } \\
\text { the organization with leading } \\
\text { competitors } \\
\text { 2. Gross operating profit } \\
\text { 3. Net operating profit } \\
\text { 4. Sales achieved }\end{array}$ \\
\hline
\end{tabular}

\section{The Empirical Study:}

The empirical study of the research based on a limited surveying questionnaire that was designed and directed to managers in travel \& leisure organizations located in Great Cairo to extract information on the respondents' awareness of the BSC framework, attitude, intention, and evaluation of the performance towards the four perspectives of $\mathrm{BSC}$

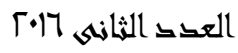

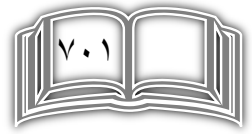
المجلد السابع 
Measuring the Alignment of BSC with the Egyptian Travel

Emad Elwy Habib

framework. The sample included travel \& Leisure organizations managers who were exposed to the BSC framework or previously used or non-user of the framework.

Judgmental sample included 40 travel \& leisure organizations the geographical area located in Great Cairo and 350 questionnaires distributed travel \& Leisure organizations top, middle, and first line managers; Covering the performance evaluation process using the BSC. proposed model. Our responds were 211, and 31 questionnaires were excluded for non-validity, to reach approximately 180 valid questionnaires that were returned with respondent rate of $51.43 \%$ which is statistically acceptable for data analysis. Data obtained was analysed by using Statistical Package for Social Sciences (SPSS). Frequencies and percentages were made for all the constructs, a bundle of different techniques were used including cross tabulation, descriptive statistics, correlation coefficient and regression analysis. Secondary data was collected from relevant textbooks, journals. The implementation interval is chosen at the beginning of spring 2010. The research contributed to knowledge on analytical performance measurement process, its requirements, problems and needs of the Travel \& Leisure industry to improve its performance evaluation process, design of proposed model for improving the performance measurements process in the 


\section{جامهة شناة السويس، - كلية التجارة الإسماعيلية}

Measuring the Alignment of BSC with the Egyptian Travel

Emad Elwy Habib

Travel \& Leisure industry and increasing travel and Leisure organizations profits.

Statistical analysis:

Table (5): Frequency distribution

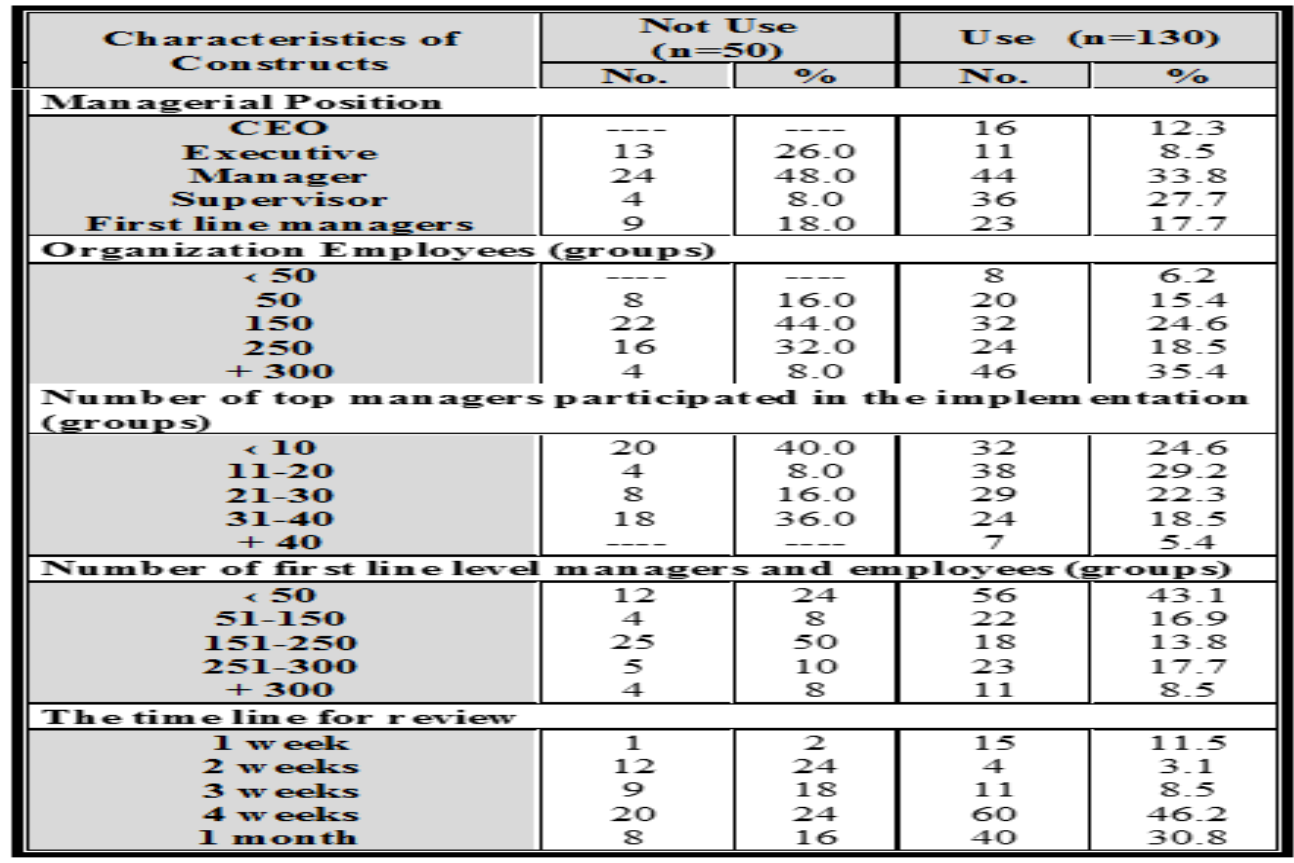

Table (5) shows, the managerial position, Organizational Employees, Number of top managers participated in the implementation, Number of first line-level managers and employees, the timing of balanced scorecard, and the time line for review were presented to clarify the skills of the respondents and the if their organizations are applying the

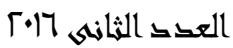

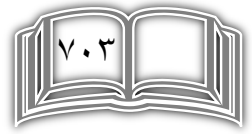
المجلد السابع 
Measuring the Alignment of BSC with the Egyptian Travel

BSC., who is involved and engaged, and the time for review. In addition to, clarifying and differentiating between the respondents whom are familiar and not familiar with the BSC. The researcher is precise and confident with the answers of the questionnaire that are based on the characteristics of respondents in the outcomes of the frequencies.

Pearson Correlation Table (6) indicated that all the constructs (BSC perspective) financial perspective, Internal operating processes Perspective, Employee innovation/learning and growth Perspective, and Client Perspective are significant at the 0.01 level, in addition to the positive relationship between the BSC perspective and performance measurement. The researcher applied the reliability test on outcomes of the study through Inter Consistency Test (ICT), Pearson Correlation Coefficient used to check validity of the four perspectives of the study and Cronbach' Alpha test for measuring the reliability of constructs (perspective) for measuring the constructs of the study. Moreover, table (6) illustration of the validity and reliability outcomes, which clarified that all the constructs of the study are highly significant as indicated by the correlation level at a high level of significant at 0.01 ranged from 0.445 to 0.878 with one insignificant exception of the sub-construct related to the providence of the organizations for the staff members to get academic or 
Measuring the Alignment of BSC with the Egyptian Travel

Emad Elwy Habib

professional degrees for the staff less than minimum level of significance at 0.05 .

The reliability levels of Cronbach' Alpha ranged from 0.806 to 0.87 , which indicated higher levels of reliability and homogeneity between the sub-constructs within the four perspectives. Based on validity and reliability of the research tool (questionnaire), the researcher concluded that the questionnaire tests well the reliability and validity of testing the hypothesis of the research. And the proposed constructs of the model tested are with great degree of validity and reliability to represent the performance development process in the Travel \& Leisure industry.

Table (6): Reliability and Validity tests for the four perspectives of the model

\begin{tabular}{|l|c|c||}
\hline \multicolumn{1}{|c|}{ Model's Constructs and Variables } & $\begin{array}{c}\text { Pearson Correlation } \\
\text { coefficient }\end{array}$ & $\begin{array}{c}\text { Chronbach' } \\
\text { Alpha }(\alpha)\end{array}$ \\
\hline Financial Perspective & $0.746^{* *}$ & 0.806 \\
\hline Internal operating processes Perspective & $0.598^{* *}$ & 0.871 \\
\hline $\begin{array}{l}\text { Employee innovation/learning and growth } \\
\text { Perspective }\end{array}$ & $0.725^{* *}$ & 0.868 \\
\hline Client Perspective & $0.617^{* *}$ & 0.822 \\
\hline
\end{tabular}

** Significant at the 0.01 level

* Significant at the 0.05 level

\section{Testing of Hypotheses:}

The researcher will present next the statistical analysis outcomes that will support the hypotheses verification and achieve the research objectives. 
First Hypothesis $\left(\boldsymbol{H}_{1)}\right.$ : There is no significant relationship between BSC framework and the Travel and Leisure organization's performance.

The researcher used Pearson Correlation and Stepwise Regression Analysis statistical approaches to verify H1.

1. Pearson Correlation used to indicate the co-relation between the constructs and the performance of the travel and leisure organizations.

Table (7): Pearson Correlation Coefficient

\begin{tabular}{|c|c|c|c|c|}
\hline Constructs & Q1t & Q2t & Q3t & Q4t \\
\hline Q1t & 1 & $0.776 * *$ & $0.885 * *$ & $0.848 * *$ \\
\hline$Q^{2 t}$ & & 1 & $0.788 * *$ & $0.759 * *$ \\
\hline Q3t & & & 1 & $0.865 * \hbar$ \\
\hline Q4t & & & & 1 \\
\hline
\end{tabular}

** Denote to Pearson Correlation Coefficient significant at 0.01 level of significant Table (7) indicated that all the constructs of the model are significant at the 0.01 level and indicated the positive relationship between the perspectives and each other within a ranged from 0.759 to 0.885 which indicated the strength of this relationships.

2. Stepwise Regression Analysis to indicate the best combination of constructs that can improve the performance of the travel and leisure organizations and explain the performance changes. 
Table (8): Stepwise Regression model

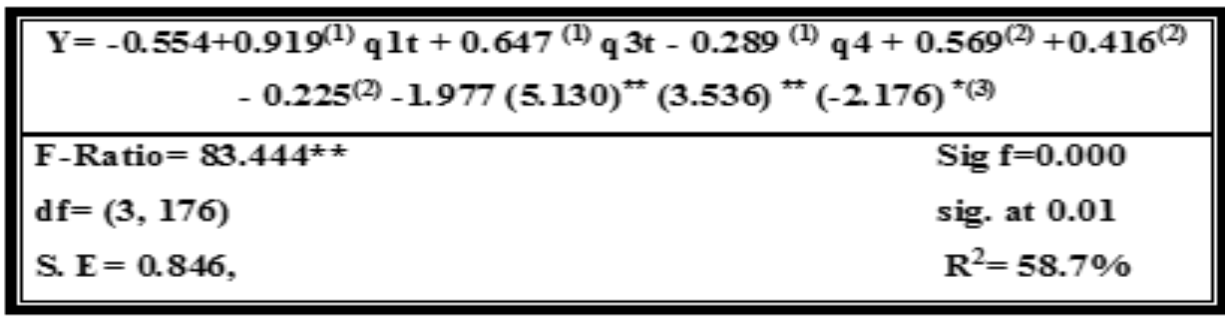

** Denote to the F\& T- test is significant at 0.01 . * Denote to the T-test is significant at 0.05 .

Table (8) showed the most influential perspectives on the performance of the travel and leisure organizations according to coefficient constructs of each perspective. These perspectives are, Financial perspective positive relation, Employee innovation/learning and growth Perspective positive relation, Client perspective negative relation, and Internal operating processes perspective excluded. The value of the F-Test equals 83.444 which is significant at the 0.01 level with degree of freedom $\mathrm{df}=(3,176)$. This value indicates that the model is highly significant and can be relied on and applied with minimum errors to calculate the effect of the three previous perspectives on the performance of travel and leisure organizations.

The correlation $\left(\mathrm{R}^{2}\right)$ value indicated that the proposed model can explain 59\% of constructs that can affect the travel and leisure organizations performance. From the previous analysis we can deny and reject the first hypothesis. The statistics and 
Measuring the Alignment of BSC with the Egyptian Travel

analysis indicated that the BSC framework has great impact on the performance of the Travel \& Leisure organizations and this was represented by rejecting the first hypothesis. These outcomes reflected the importance of the four perspectives of the BSC framework in the following rank: Financial perspective, Employee innovation/learning and growth Perspective, Client perspective, and at last Internal operating process perspective.

Second Hypothesis $\left(\mathbf{H}_{2}\right)$ : There is no effect of the internal constructs of BSC framework (Internal operating processes, and Employee innovation/learning and growth Perspective) on the financial performance taking into consideration the client prospective. Path Analysis and Direct and Indirect Effect Analysis as statistical approaches are used to verify the second hypothesis, that can be illustrated in figure (2):

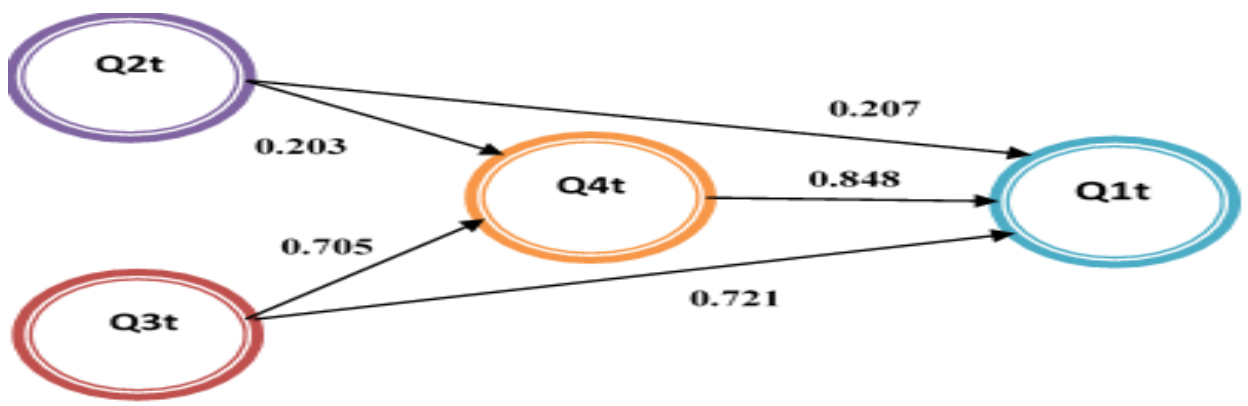

Figure (2): Path analysis Diagram 
Measuring the Alignment of BSC with the Egyptian Travel

Emad Elwy Habib

The path analysis was conducted based on table (9):

1. Independent constructs represented via internal operating processes $(\mathrm{Q} 2 \mathrm{t})$, and Employee learning and growth $(\mathrm{Q} 3 \mathrm{t})$

2. Dependent constructs represented via financial perspective (Q1t).

3. Intermediate variable represented by Client perspective (Q1t).

Table (9): Direct and Indirect Effect outcomes for The Path Analysis:

\begin{tabular}{|c|c|c|c|}
\hline \multirow{2}{*}{$\begin{array}{l}\text { Independent } \\
\text { constructs }\end{array}$} & \multicolumn{2}{|l|}{ Indirect Effect } & \multirow{2}{*}{$\begin{array}{l}\text { Direct effect } \\
\text { (value) }\end{array}$} \\
\hline & Path & Value & \\
\hline $\mathbf{Q}_{2} \mathbf{t}$ & $\mathrm{Q}_{2} \mathrm{t} \underset{0-203}{\underset{\longrightarrow}{\longrightarrow}} \mathrm{Q}_{4} \mathrm{t} \underset{0.848}{\underset{\longrightarrow}{\longrightarrow}} \mathrm{Q}_{1} \mathrm{t}$ & +0.172 & +0.207 \\
\hline $\mathbf{Q}_{3} t$ & $\mathrm{Q}_{3} \mathrm{t} \underset{0-705}{\longrightarrow} \mathrm{Q}_{4} \mathrm{t} \underset{0.848}{\longrightarrow} \mathrm{Q}_{1} \mathrm{t}$ & +0.598 & +0.721 \\
\hline
\end{tabular}

The researcher concluded the following from table (9):

There is a preference for direct effect outcomes over the indirect outcomes for the independent constructs. And a preference for the Employee innovation/learning and growth Perspective on the internal operating processes perspective which was revealed by the direct and indirect effect analysis. So that all the effects of the independent constructs were positive despite of being direct or indirect.

The statistical analysis indicated the significance of the Internal operating processes perspective, Employee innovation/ learning and growth Perspective with their direct and indirect effect on the financial perspective through 
Measuring the Alignment of BSC with the Egyptian Travel

intermediate constructs which is the client perspective. The statistical analysis indicated also, the superiority of the Employee innovation/ learning and growth Perspective through the values presented for the direct and indirect effect on the financial perspective over the values presented for the Internal operating processes perspective. These outcomes indicated the importance of financial performance measures presented by the researcher regarding these two perspectives and their significance for the performance development process. Based on the previous outcomes the second hypothesis was rejected.

Third Hypothesis $\left(\mathbf{H}_{3}\right)$ : There are no significant statistical differences between sample responses towards the BSC perspectives and the organization performance.

T-Test and the Mann-Whitney test as statistical approaches are used to verify the third hypothesis, as shown in table (10). T-test identify if there are statistical differences between the means of two groups. T-test is appropriate to compare the means of two groups, and especially appropriate as the analysis for the post test-only two-group randomized experimental design.

Mann-Whitney test: Table (11) a non-parametric test (distribution-free) used to compare two independent groups of sampled data. It is the alternative test to the t-test. Mann- 
Measuring the Alignment of BSC with the Egyptian Travel

Emad Elwy Habib

Whitney test is a non-parametric test that is used to compare two population means that come from the same population.

Table (10): Outcomes of T-Test

\begin{tabular}{|c|c|c|c|c|c|c|}
\hline \multirow[b]{2}{*}{ Persp ectives } & \multirow[b]{2}{*}{ BSC } & \multicolumn{3}{|c|}{ Descriptive Statistics } & \multirow{2}{*}{ 总 } & \multirow{2}{*}{ है } \\
\hline & & Mean & S.E & $\begin{array}{c}\text { CI for mean } \\
\text { with } 95 \%\end{array}$ & & \\
\hline \multirow{2}{*}{$\begin{array}{l}\text { F in an cial } \\
\text { Perspectiv e }\end{array}$} & Not U se (a) & 3.058 & 0.087 & $(2.88,3.233)$ & \multirow{3}{*}{$\begin{array}{l}4.212^{* *} \\
(120)\end{array}$} & \multirow{3}{*}{$\mathbf{a} d \mathbf{b}$} \\
\hline & Use (b) & 3.540 & 0.073 & $(3.402,3.683)$ & & \\
\hline \multirow{2}{*}{$\begin{array}{l}\text { Internal operating } \\
\text { p rocesses }\end{array}$} & Not U se (a) & 3.242 & 0.109 & $(3.024,3.460)$ & & \\
\hline & Use (b) & 3.885 & 0.076 & $(3.734,4.035)$ & $\begin{array}{c}4.848^{* *} \\
(100)\end{array}$ & $\mathbf{a} d \mathbf{b}$ \\
\hline \multirow{2}{*}{$\begin{array}{l}\text { Employee } \\
\text { innovation/learning } \\
\text { \& grow th } \\
\text { perspective. }\end{array}$} & Not Use (a) & 3.068 & 0.112 & $(2.843,3.292)$ & \multirow[b]{2}{*}{$\begin{array}{c}4.174^{* *} \\
(178)\end{array}$} & \multirow[b]{2}{*}{$\mathbf{a} \mathbf{d b}$} \\
\hline & Use (b) & 3.625 & 0.071 & $(3.485,3.765)$ & & \\
\hline \multirow{2}{*}{ Client Perspective } & Not U se (a) & 3.267 & 0.111 & $(3.044,3.489)$ & \multirow{2}{*}{$\begin{array}{l}3.986^{* *} \\
(119)\end{array}$} & \multirow{2}{*}{$\mathbf{a} d \mathbf{b}$} \\
\hline & (U) (bD) & 38012 & Q1022 & (3) 6390,4024$)$ & & \\
\hline
\end{tabular}

** denote to that T-test values have a Sig. At (0.01) level of significant.

The outcomes of table (10) indicated that there was high acceptance to apply the different perspectives of the BSC. This was clear because all the outcomes were significant at 0.01 in favour of all the BSC perspectives implementation. Table (11) illustrated the impact of using BSC on the organization performance. 
Measuring the Alignment of BSC with the Egyptian Travel

Emad Elwy Habib

Table (11): Mann-Whitney test

\begin{tabular}{|c|c|c|c|}
\hline \multirow{2}{*}{ Groups } & \multirow{2}{*}{$\begin{array}{l}\text { Mean } \\
\text { Ranks }\end{array}$} & \multicolumn{2}{|c|}{ Descriptive Statistics } \\
\hline & & Mean & S.E \\
\hline Not Use & 77.7 & 3.580 & 0.134 \\
\hline Use & 95.42 & 3.823 & 0.124 \\
\hline \multicolumn{4}{|c|}{$Z=2.136$, Sig $=0.033(\mathrm{P}<0.05)$ Sig. at 0.05} \\
\hline
\end{tabular}

The outcomes from Mann-Whitney test indicated that there was a significant statistical difference for BSC implementation and this was emphasised by the outcomes of Mann- Whitney test and outcomes of Mean Ranks. The statistical analysis indicated the significant of all the measures proposed through the model and its positive relationship with the dependent constructs which is the development process. The T-Test and the Mann-Whitney analysis indicated along with the F-value the significant of the BSC model and also, indicated the usage of the model from the respondent's answers analysis. These outcomes indicate the importance of the accounting performance measures presented by the researcher regarding the four perspectives and their significance for the performance development process. Based on the previous outcomes the third hypothesis was rejected.

Fourth Hypothesis $\left(\mathbf{H}_{\mathbf{4}}\right)$ : The proposed model is not a valid tool for improving the performance of the Travel \& Leisure industry. 
Measuring the Alignment of BSC with the Egyptian Travel

Emad Elwy Habib

Two Sample Z-test and the Kolmogorov-Smirnov test as statistical approaches are used to verify the fourth hypothesis, to compare two proportions created by two random samples or two subgroups of one random sample. Table (12) shows the outcomes of Kolmogorov-Smirnov test (K-S test), a nonparametric test for the equality of continuous, onedimensional probability distributions that can be used to compare a sample with a reference probability distribution to compare two samples.

The researcher concluded from table (12), that Z-Test outcomes indicated a significant statistical difference in favour to BSC implementation in Travel \& Leisure organizations. These differences indicated the emphasis of the organization on continuous Improvement of the organization result on the long term, increasing client orientation and focus, and that the framework supports the organization to implement the long term strategy, in addition to enhancing the investment in intangibles.

Table (12): Outcomes of Two Sample Z-Test and Kolmogorov-Smirnov

\begin{tabular}{|l||l||l||l||}
\hline \multicolumn{1}{|l||}{} & The benefits of the framework: & Z-Test & Sig. \\
\hline \hline 1 & $\begin{array}{l}\text { Continuous Improvement of the organization result } \\
\text { on the long term. }\end{array}$ & $z=7.17$ & $0.000(P<0.01)$ \\
\hline \hline 2 & $\begin{array}{l}\text { Improved understanding of cause and effect } \\
\text { relationships in the organization. }\end{array}$ & $z=0.10$ & $0.919(\mathrm{~N} . S)$ \\
\hline \hline 3 & Increasing client orientation and focus & $z=2.29$ & $0.022(P<0.05)$ \\
\hline 4 & Enhancing the investment in intangibles & $z=3.45$ & $0.001(P<0.01)$ \\
\hline
\end{tabular}

العد المثانهى

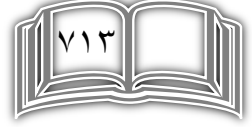

المجلد السابي 
Measuring the Alignment of BSC with the Egyptian Travel

Emad Elwy Habib

\begin{tabular}{|c|c|c|c|}
\hline 5 & $\begin{array}{l}\text { Higher consideration of the non-financial drivers of } \\
\text { performance. }\end{array}$ & $z=1.38$ & 0.167 (N.S) \\
\hline 6 & $\begin{array}{l}\text { Enhancing business process re-engineering } \\
\text { opportunities. }\end{array}$ & $z=0.30$ & 0.762 (N.S) \\
\hline 7 & $\begin{array}{l}\text { The framework accomplishes the organization } \\
\text { objectives. }\end{array}$ & $\begin{array}{l}\mathrm{K}- \\
\mathrm{S}=\mathbf{1 . 5 5 3}\end{array}$ & $0.016(P<0.05)$ \\
\hline 8 & $\begin{array}{l}\text { The framework supports the organization to } \\
\text { implement the long term strategy }\end{array}$ & $\begin{array}{l}\mathrm{K}- \\
\mathrm{S}=3.273\end{array}$ & $0.000(P<0.01)$ \\
\hline 9 & $\begin{array}{l}\text { The framework designed for creating tangible and } \\
\text { intangible strategies. }\end{array}$ & $\begin{array}{l}\mathrm{K}- \\
\mathrm{S}=\mathbf{1 . 6 3 6}\end{array}$ & $0.000(P<0.01)$ \\
\hline 10 & $\begin{array}{l}\text { The framework encompasses a formal written } \\
\text { balance scorecard strategic implementation plan. }\end{array}$ & $\begin{array}{l}\mathrm{K}- \\
\mathrm{S}=\mathbf{0 . 5 0 8}\end{array}$ & 0.958 (N.S) \\
\hline \multicolumn{4}{|c|}{ Framework implementation problems: } \\
\hline 1 & Lack of planning and communication. & $\mathbf{z}=\mathbf{0 . 0 2}$ & 0.983 (N.S) \\
\hline 2 & High cost for BSC processing. & $z=1.57$ & 0.116 (N.S) \\
\hline 3 & "Time consuming in the implementation. & $z=2.36$ & $0.018(P<0.05)$ \\
\hline 4 & $\begin{array}{l}\text { Complexity in the implementation in adjacent with } \\
\text { inadequate KPI's. }\end{array}$ & $z=1.25$ & 0.210 (N.S) \\
\hline 5 & $\begin{array}{l}\text { Inadequate involvement of all the organization } \\
\text { employees. }\end{array}$ & $z=0.76$ & 0.449 (N.S) \\
\hline
\end{tabular}

These constructs are consecutively ranked in accordance to their importance in the proposed model. The rest of the constructs were not significant to the implementation of the proposed model.

Kolmogorov-Smirnov test outcomes indicated that there were significant statistical differences from the sample responses at 0.05 level. The probability distribution of responses indicated the tendency toward the Proposed model implementation which conorganizationed by the acceptance of 
Measuring the Alignment of BSC with the Egyptian Travel

Emad Elwy Habib

$69.2 \%$ of the sample responses of BSC users to the proposed model implementation against $48 \%$ of non-BSC users. Moreover, Kolmogorov-Smirnov test indicated that there were significant statistical differences from the sample responses which was significant at 0.01 level. The probability distribution of responses indicated the tendency toward the proposed model implementation which conorganizationed by the acceptance of $80 \%$ of the sample responses of BSC users to the proposed model implementation against $32 \%$ of nonBSC users.

Z-Test outcomes indicated that there was a significant statistical difference against BSC implementation in Travel \& Leisure organizations regarding Time consuming in the implementation element. The result was verified by the sample responses as $24 \%$ of the non-BSC users against $41.5 \%$ of BSC users. The rest of the constructs have no significant statistical differences as a problem in implementing the proposed model.

The outcomes from Kolmogorov-Smirnov test indicated that there were significant statistical differences from the sample responses which was significant at 0.01 level. The probability distribution of responses indicated the tendency toward the Proposed model implementation which conorganizationed by the acceptance of $69.3 \%$ of the sample responses of BSC users

العد الثمانهى 17 
Measuring the Alignment of BSC with the Egyptian Travel

to the proposed model implementation against $42 \%$ of nonBSC users.

The framework has balance scorecard implementation plan in written element has no significant statistical differences between the non-BSC users against BSC users.

The statistical analysis indicated that all of the proposed measures in the model significant, and its positive relationship with the dependent constructs which is the development process, which indicated the importance of the proposed model from the respondents' perception. Moreover, the outcomes in return indicated the possibility of the implementation of the proposed model formally as a written plan considering the barriers of implementation. Based on the previous outcomes the forth hypothesis was denied and rejected.

\section{Research Outcomes:}

$>$ Performance measures used in the Egyptian travel and leisure organizations has to be modified by developing more efficiency measures and by directing these measures more toward other perspectives than the financial perspective.

$>$ The proposed model application will enhance the accounting performance measures used in the travel \& 
Measuring the Alignment of BSC with the Egyptian Travel

leisure industry by trying to present quantitative measures for the four perspectives of the model.

$>$ Empirical study indicated also, that some of the measures included in the model is already exist but without being taken into consideration in the overall evaluation process.

$>$ The empirical outcomes of the proposed model show that non-financial performance measures (i.e., the learning and growth perspective, internal operating process perspective, and client perspective) not only directly influence the financial performance measures, but also indirectly affect performance through the cause-and-effect relationships among different perspectives.

\section{Recommendations:}

$>$ The adoption of proposed model is recommended in order to verify the efficiency of performance measurement framework and identify aspects of strength (weakness) and identify opportunities for improvement.

$>$ All members of the staff play a vital role in achieving the travel and leisure organizations mission. Thus it is important that skills and knowledge are regularly updated to enable them to continue to per-form at the highest level. To this end the travel and leisure 
Measuring the Alignment of BSC with the Egyptian Travel

organizations are committed to the developed plan for its staff.

$>$ Conducting an annual program of staff development courses and activities which should be continuously monitored and updated to achieve balance between the needs of the travel and Leisure organizations and skilled staff available.

$>$ Modify the reporting framework used to cope with the new quantifying information needed by the model.

\section{Future Research:}

The approach outlined in this study can be replicated in other nations, industries and organizations. Therefore, future studies may focus on validating the proposed BSC model and associated strategic objectives and performance measures, as well as on implementing the BSC to the other industries or organizations to test the effectiveness of this BSC strategic management approach. 


\section{References:}

1. Anderson, E. W., Fornell, C., \& Lehmann, D. R. (1994). Customer satisfaction, market share, and profitability: Findings from Sweden. The Journal of Marketing, 53-66.

2. Bititci, U. S., Carrie, A. S., \& McDevitt, L. (1997). Integrated performance measurement systems: a development guide. International journal of operations \& production management, 17(5), 522-534.

3. Brander Brown, J. and McDonnell, B. (1995), "The balanced scorecard: short-term client or long-term resident?", International Journal of Contemporary Travel \& Leisure Management, Vol. 7 Nos 2/3, pp. 7-11.

4. Collis, J., Holt, A., \& Hussey, R. (2012). Business accounting: an introduction to financial and management accounting. Palgrave Macmillan.

5. Eccles, R.G. (1991), "The performance measurement manifesto", Harvard Business Review, Vol. 69, January/February, pp. 131-7.

6. Epstein, M. And Manzoni, J.F. (1998), "Implementing corporate strategy: from tableaux de board to balanced scorecards", European Management Journal, Vol. 16 No. 2, pp. 190-203.

7. Gail S. Perry, (2010), "Evidence of a Mature Scorecard: The Power of Alignment!”, Balanced Scorecard Institute, a Strategy Management Group organization, pp. 1-4.

8. Giannopoulos, G., Holt, A., Khansalar, E., \& Cleanthous, S. (2013). The use of the Balanced Scorecard in small companies. International Journal of Business and Management, 8(14), 1.

9. Gumbus, A., \& Lussier, R. N. (2006). Entrepreneurs use a balanced scorecard to translate strategy into performance measures. Journal of Small Business Management, 44(3), 407-425. 
Measuring the Alignment of BSC with the Egyptian Travel

Emad Elwy Habib

10. Gupta, P. K., \& Tyagi, R. K. (2008). A complete and balanced service scorecard: creating value through sustained performance improvement. FT Press.

11. Hao-Chen Huan, (2007), "Strategic Performance Measurement and Value Drivers: Evidence from International Tourist Travel and leisure organizations in an Emerging Economy “, The Service Industries Journal, Volume 27, Issue 8 December 2007, pp. 1111 - 1128.

12. Howard Rohm, (2002), "Performance Measurement in Action", PERFORM Review, Vol. 2 \& 3 Issue 2, pp. 3-8.

13. Howard Rohm, (2008), "Using the Balanced Scorecard to Align Your Organization “, Balanced Scorecard Institute, a Strategy Management Group organization, pp. 1-4.

14. Huckestein, D. And Duboff, R. (1999), "Hilton Travel and leisure organizations: a comprehensive approach to delivering value for all stakeholders", Cornell Travel and Leisure organizations and Restaurant Administration Quarterly, August, pp. 28-38.

15. Inamdar, N., Kaplan, R. S., \& Reynolds, K. (2002). Applying the balanced scorecard in healthcare provider organizations/Practitioner's Response. Journal of healthcare management, 47(3), 179-196.

16. Kaplan, R. S., \& Norton, D. P. (2008). The execution premium: Linking strategy to operations for competitive advantage. Harvard Business Press.

17. Kaplan, R., and Norton, David, (1996), "The Balanced Scorecard. Translating Strategy into Action", Boston: Harvard Business School Press, Boston, MA.

18. Kaplan, R.S. and Norton, D.P. (1992), "The balanced scorecard measures that drive performance", Harvard Business Review, January/February, pp. 1-79.

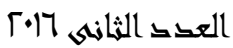


Measuring the Alignment of BSC with the Egyptian Travel

Emad Elwy Habib

19. Kaplan, R.S. and Norton, D.P. (2001), The Strategy-Focused Organisation, Harvard Business School Press, Boston, MA.

20. Kemeny, J., Girdner, K., Bobo, T., \& Norton, B. (1999), Improvements for fragmentation measurement by digital imaging: accurate estimation of fines. In Sixth International Symposium for Rock Fragmentation by Blasting, SAIMM (pp. 103-110).

21. Kennerley, M., \& Neely, A. (2002). A framework of the factors affecting the evolution of performance measurement systems. International journal of operations \& production management, 22(11), 1222-1245.

22. NAGY, A., BĂBĂIłĂ, C. A. R. M. E. N., \& ISPAS, (2010), A Nonfinancial performance measurement of hotel activity

23. Neely, A. (2005). The evolution of performance measurement research: developments in the last decade and a research agenda for the next. International Journal of Operations \& Production Management, 25(12), 1264-1277.

24. Neely, A. D., and Adams, C., (2001), "The Performance Prism Perspective", Journal of Cost Management, pp. 6-12.

25. Neely, A.D., Gregory, M.J. and Platts, K.W. (1995), “'Performance measurement framework design: a literature review and research agenda", International Journal of Operations \& Production Management, Vol. 15 No. 4, pp. 80-116.

26. Nigel Evans, International Journal of Contemporary Travel \& Leisure Management Vol.17 No.5, 2005 pp.376-400 Emerald Group Publishing Limited

27. Niknazar, P. (2009). Application of integrated DEA-BSC model in strategic management. In 6th international conference of management. 
Measuring the Alignment of BSC with the Egyptian Travel

Emad Elwy Habib

28. Norreklit, H. (2000). The balance on the balanced scorecard a critical analysis of some of its assumptions. Management accounting research, 11(1), 65-88.

29. Paul. Phillips, Panos, Louvieris, (2005), Performance Measurement Systems in Tourism, Hospitality, and Leisure Small Medium-Sized Enterprises: A Balanced Scorecard Perspective, Journal of Travel Research, Vol. 44, 2005, pp. 201- 211.

30. Perkins, M., Grey, A., \& Remmers, H., (2014). What do we really mean by "Balanced Scorecard"? International Journal of Productivity and Performance Management, 63(2), 148-169.

31. Pieper, "Reading the Right Signals: How to Strategically Manage with Scorecards," Healthcare Executive 20 no. 3 (May/June 2005): 814.

32. Poureisa, A., Ahmadgourabi, M. B., \& Efteghar, A. (2013). Balanced scorecard: A new tool for performance evaluation. Interdisciplinary Journal of Contemporary Research in Business, 5(1), 974-978.

33. Rigby, D., \& Bilodeau, B. (2011). Management tools \& trends 2011. Bain \& Company. Retrieved July, 5, 2012.

34. Salem, M. A., Hasnan, N., \& Osman, N. H. (2012). Balanced Scorecard: weaknesses, strengths, and its ability as performance management system versus other performance management systems. Journal of Environment and Earth Science, 2(9), 1-10.

35. Von Bergen, C. W., \& Benco, D. C. (2004). A balanced scorecard for small business. In Proceedings of the United States Association for Small Business and Entrepreneurship Conference. Dallas, Texas (pp. 15-18).

36. Webster, F.E. (1992), "The changing role of marketing in the corporation", Journal of Marketing, Vol. 56, October, pp. 1-17.

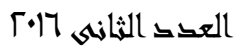

